\title{
THE FATE OF COMPOST-DERIVED PHOSPHORUS IN URBAN GARDENS
}

\author{
G. SMALL ${ }^{1}$, P. SHRESTHA \& A. KAY \\ Department of Biology, University of Saint Thomas, United States.
}

\begin{abstract}
Urban agriculture has been expanding rapidly in recent years, and it has the potential to recycle nutrients from local food wastes into new foods through the use of compost as growth medium. Composts typically have low nitrogen: phosphorus $(\mathrm{N}: \mathrm{P})$ ratios, and in urban gardens, when composts are typically applied to soils annually to meet the $\mathrm{N}$ demand of crops, excess $\mathrm{P}$ can build up and be prone to leaching. We measured dissolved $\mathrm{P}\left(\mathrm{PO}_{4}{ }^{3-}\right)$ and $\mathrm{N}\left(\mathrm{NO}_{3}{ }^{-} \& \mathrm{NH}_{4}{ }^{+}\right)$losses in the leachate from experimental raised-bed garden plots that received one of two commonly used composts (municipal organics compost derived from food scraps or cow manure derived compost) at three different application levels $\left(15 \%, 35 \%\right.$, or $50 \%$ by volume). $\mathrm{PO}_{4}{ }^{3-}$ concentrations in leachate from garden plots receiving manure composts were high, ranging from 5 to $11 \mathrm{mg} / \mathrm{L}$, depending on the application level. Leachate $\mathrm{PO}_{4}{ }^{3-}$ concentrations from plots receiving municipal organics composts were an order of magnitude lower, ranging from $0.5-1.2 \mathrm{mg} / \mathrm{L}$, while leachate $\mathrm{PO}_{4}{ }^{3-}$ in garden plots receiving no compost was $0.3 \mathrm{mg} \mathrm{L}^{-1}$. Cumulative mass of $\mathrm{PO}_{4}{ }^{3-}$ lost through leachate during the growing season ranged from 1.2 to $4.2 \mathrm{~g} / \mathrm{m}^{2}$ for manure compost treatments, compared to $0.12-0.72 \mathrm{~g} / \mathrm{m}^{2}$ for municipal compost treatments, and $0.06 \mathrm{~g} / \mathrm{m}^{2}$ for soil with no compost. Leachate accounted for $0-37 \%$ and $18-45 \%$ of dissolved $\mathrm{P}$ and $\mathrm{N}$ exported from garden plots, respectively. The high application rate of municipal compost significantly increased crop yield relative to the control treatment. P lost from leachate and removed through harvest only represented $1-10 \%$ of total $\mathrm{P}$ applied as compost, suggesting that soil build-up was the dominant fate of $\mathrm{P}$ in this study. Our results illustrate the potential trade-off in urban agriculture between crop production and recycling P efficiently from urban food waste.
\end{abstract}

Keywords: compost, nitrogen, nutrient leaching, nutrient recycling efficiency, phosphorus, urban agriculture, water quality.

\section{INTRODUCTION}

Urban ecosystems are characterized as being extremely heterotrophic, with a high throughput of materials, and low internal cycling [1]. Cities rely on a land area 100-300 times larger than the city itself for the provisioning of food, water, and energy, and the assimilation of waste [2]. Urban agriculture has been proposed as a means of partially closing this loop, recycling nutrients from organic waste back into the human food system [3], and making cities less reliant on imported food [4].

Although there are many potential social, economic, environmental, and public health benefits of urban agriculture [5], [6], there is a potential tradeoff between maximizing nutrient recycling in cities and minimizing subsequent nutrient pollution through runoff or leachate. Organic wastes typically have low nitrogen:phosphorus (N:P) ratios relative to crop nutrient demand [7], so that if compost is applied based on crop N-demand, soils receive excess $\mathrm{P}$. While soils have the capacity to naturally bind $\mathrm{P}$, at high $\mathrm{P}$ concentrations this capacity can be exceeded, [8], and instead, soils become a source of $\mathrm{P}$ export. Over time, excess $\mathrm{P}$ applications can lead to $\mathrm{P}$ buildup along hydrologic flowpaths which contributes $\mathrm{P}$ losses to drainage water resulting in water pollution that lasts for decades or centuries [9]. 
Evidence from recent studies indicates the potential for excessive $\mathrm{P}$ application in urban agriculture. A study of urban food gardens in Chicago documented excessive fertilization and soil P levels averaged 263 ppm [10], ten-fold higher than optimal levels for vegetable gardens [11]. Thirty-eight percent of domestic gardens surveyed in Flanders had P levels classified as 'high' or 'very high' relative to optimal agronomic standards [12]. An analysis of Montreal's urban agriculture system [13] documented that 27 times more $\mathrm{P}$ is applied as compost than is harvested in crops each year, resulting in P loss or soil build-up of $175 \mathrm{~kg}$ P/ha/y across the $18 \mathrm{~km}^{2}$ of cultivated land in the city. An analysis of urban and peri-urban farms in Nigeria, Burkina Faso, and Mali documented large annual surpluses of P (83-780 kg/ha/y) and N (74-1127 kg/ha/y) resulting in nutrient loss to groundwater [14]. Given the rapid expansion of urban agriculture, this excess $\mathrm{P}$ has the potential to create hotspots of nutrient pollution.

Despite increasing evidence of over-application of $\mathrm{P}$ in urban agriculture, we lack understanding of how different soil amendment practices affect $\mathrm{P}$ use efficiency, and what fraction of this excess $\mathrm{P}$ is lost or exported through leachate. We measured leachate export and nutrient recycling efficiencies for $\mathrm{P}$ and $\mathrm{N}$ for vegetables grown in replicated raised bed plots using two different types of compost at three different compost: soil ratios. We hypothesize that nutrient use efficiency decreases and nutrient export through leachate increases with increasing compost application rates.

\section{METHODS}

\subsection{Experimental set-up}

This experiment took place at the University of Saint Thomas (Saint Paul, Minnesota, USA), using 36 replicated raised-bed garden plots with dimensions of $1 \mathrm{~m}$ length $\mathrm{x} 0.3 \mathrm{~m}$ width $\mathrm{x}$ $0.3 \mathrm{~m}$ depth. Prior to the experiment, soil in these plots (which had been used in previous years) was removed and homogenized. Initial soil chemistry, and nutrient content of the two compost varieties are presented in Table 1.

Table 1: Physiochemical properties of garden soil and compost samples.

\begin{tabular}{lll}
\hline & Garden soil & \\
\hline $\mathrm{NO}_{3}-\mathrm{N}(\mathrm{ppm})$ & 3.5 & \\
Bray P (ppm) & 20 & \\
Available K (ppm) & 72 & \\
Organic matter $(\%)$ & 3 & Manure compost \\
$\mathrm{pH}$ & 7.8 & 39.17 \\
\hline & Municipal compost & 1.68 \\
\hline Total C (\%) & 19.26 & 0.60 \\
Total N (\%) & 1.11 & 0.60 \\
Total P (\%) & 0.16 & 23.32 \\
Total K (\%) & 0.41 & 2.80 \\
C:N ratio (mass) & 17.35 & 116.4 \\
N:P ratio (mass) & 6.94 & \\
Bulk density (g dry mass/L) & 490.8 & \\
\hline
\end{tabular}


Each raised-bed plot was randomly allocated one of seven compost-soil mixtures (ratios are based on volume): $100 \%$ soil; $15 \%$ municipal compost $+85 \%$ soil; $35 \%$ municipal compost $+65 \%$ soil; $50 \%$ municipal compost $+50 \%$ soil; $15 \%$ manure compost $+85 \%$ soil; $35 \%$ manure compost $+65 \%$ soil; and $50 \%$ manure compost $+50 \%$ soil. The amount of $\mathrm{P}$ added in the form of compost ranged from 11 to $36 \mathrm{~g}$ in the municipal compost treatments, and from 9 to $32 \mathrm{~g}$ in the manure compost treatments. The amount of $\mathrm{N}$ added in the form of compost ranged from 76 to $248 \mathrm{~g}$ in the municipal compost treatments, and from 28 to $91 \mathrm{~g}$ in the manure compost treatments. The $100 \%$ soil treatment was applied to six replicate plots; all other treatments were applied to five replicate plots.

One row of radish seeds (Easter Egg Radish, small tricolored, from Johnny's Selected Seeds) and two rows of carrot seeds (a mixture of Yellowbunch F1 Carrot, Purple Haze F1 Carrot, and Nelson F1 Carrot, from Johnny's Selected Seeds) were planted in each raised-bed plot on 20 May 2016. After germination, seedlings were thinned to a density of approximately one seedling $/ 2.5 \mathrm{~cm}$.

Plots were watered every two to three days throughout the experiment, and soil moisture was generally maintained between 15 and $20 \%$. Water was distributed evenly over each plot for a set amount of time (typically 30, 45, or 60 seconds), and volume of water was estimated by measuring the time required to fill an 11-L bucket.

\subsection{Plant analysis, and nutrient use efficiency}

Radishes were harvested on 29 June, and replanted on 6 July. Carrots and replanted radishes were harvested on 15 August, marking the end of the experiment. The total experiment ran for 88 days. At each harvest, total wet mass of plant material removed from each plot was recorded, with stems and leaves measured separately from edible root biomass. A subsample of plant material from each experimental treatment was weighed, dried at $60^{\circ} \mathrm{C}$ for 72 hours, and re-weighed. These values were used to calculate dry weight:wet weight ratios for each crop, and these subsamples were then processed for total carbon (C), N, and P content. Dried plant samples from each subplot were ground into fine powder $(<0.5 \mathrm{~mm})$. For total $\mathrm{C}$ and $\mathrm{N}$, samples were analyzed in duplicates by combustion method in a Thermo Electron Flash EA 112 Series CN elemental analyzer (Thermo Fisher Scientific, Waltham, MA, USA). Total P was measured by ashing samples $\left(500^{\circ} \mathrm{C}\right.$ for $2 \mathrm{~h}$ ) followed by persulfate digestion, and analyzed spectrophotometrically using ascorbic acid [15], using NIST apply leaf standard (NIST SRM 1515, Sigma-Aldrich, St. Louis, MO, USA) as a reference.

Nitrogen use efficiency (NUE) and phosphorus use efficiency (PUE) were calculated as the amount of $\mathrm{N}$ or $\mathrm{P}$ removed in crops relative to the total $\mathrm{N}$ or $\mathrm{P}$ added as compost to each plot (these terms were not calculated for control treatments where no compost was added). Mass of $\mathrm{N}$ or $\mathrm{P}$ removed in crops was calculated by multiplying percent nutrient content of the crop by dry biomass.

\subsection{Nutrient leachate measurement}

We collected leachate by installing a lysimeter in the center of each raised bed. Lysimeters consisted of a plastic funnel with a diameter of $23 \mathrm{~cm}$, attached to a $1 \mathrm{~L}$ narrow-mouth polyethylene bottle. Wire mesh covered the hole in the funnel, and the funnel was filled with a $3 \mathrm{~cm}$ layer of pea gravel. A $0.6 \mathrm{~m}$ segment of Tygon tubing extended from the bottom of the bottle to the surface. Lysimeters were buried so that the top of the funnel was level with the base of the raised-bed, below the $0.3 \mathrm{~m}$ layer of soil-compost mixture. Lysimeters were 
sampled every 3-4 days throughout the growing season by using a $50 \mathrm{~mL}$ syringe to empty the collector bottle. The volume of leachate was recorded, and a $15 \mathrm{~mL}$ subsample was transferred to a plastic scintillation vial for subsequent analysis of leachate $\mathrm{PO}_{4}{ }^{3}-, \mathrm{NO}_{3}-$, and $\mathrm{NH}_{4}{ }^{+}$concentrations. Leachate concentrations were measured from all lysimeters for which $>5 \mathrm{~mL}$ of leachate was recovered. Water samples were either analyzed immediately, refrigerated if run within 48 hours, or frozen if analyzed later. Samples were diluted at a 1:10 ratio with deionized/distilled water. Leachate $\mathrm{PO}_{4}{ }^{3}$ - concentrations were analyzed using Hanna Instruments Phosphate Low Range Portable Photometer (HI96713). Leachate $\mathrm{NO}_{3}-$ and $\mathrm{NH}_{4}{ }^{+}$concentrations were analyzed using YSI Professional Plus Multiparameter Meter fitted with a Pro Series 1006 nitrate ISE sensor and a Pro Series 1004 ammonium ISE sensor.

Leachate nutrient mass was calculated for individual sampling events $(n=22)$ by multiplying nutrient concentration of the subsample of lysimeter water by the total water volume in the lysimeter: nutrient mass $(\mathrm{mg})=$ nutrient concentration $(\mathrm{mg} / \mathrm{L}) \times$ leachate volume $(\mathrm{L})$. The resulting mass numbers were divided by the lysimeter funnel area (approximately $0.04 \mathrm{~m}^{2}$ ) and scaled to the area of the raised-bed garden plot $\left(0.3 \mathrm{~m}^{2}\right)$. Cumulative mass of nutrients exported from the garden plots over the growing season was determined by summing all the individual mass flows.

We used an Analysis of Covariance to test for the effect of compost $\mathrm{N}$ or P added and compost type (manure or municipal) on crop yield, crop $\% \mathrm{P}$ and $\% \mathrm{~N}, \mathrm{PUE}$ or NUE (phosphorus or nitrogen use efficiency, respectively), and inorganic $\mathrm{P}\left(\mathrm{PO}_{4}{ }^{3}-\right)$ or $\mathrm{N}\left(\mathrm{NO}_{3}-\& \mathrm{NH}_{4}^{+}\right)$leachate. Statistical analysis was conducted using JMP Pro 13.

\section{RESULTS}

Total harvested crop wet mass ranged from 1566 to $3593 \mathrm{~g}$, and was positively related to the volume of compost added $(P=0.0254)$, but not compost type $(P=0.4536)$ or compost type $\times$ compost volume interaction $(P=0.6048)$.

Radish P-content ranged from 0.22 to $0.37 \% \mathrm{P}$, and was not affected by compost $\mathrm{P}$ added or compost type. Radish N-content ranged from 2.87 to $3.86 \% \mathrm{~N}$ (by dry mass), and was not related to compost $\mathrm{N}$ added $(P=0.1344)$, but was significantly higher for municipal compost treatments compared to manure compost treatments $(P=0.0231)$. Radish stems and leaves made up $33.7 \%$ of the total harvested biomass of radishes. Carrot $P$ content ranged from 0.13 to $0.46 \% \mathrm{P}$, and was not related to compost $\mathrm{P}$ added or compost type. Carrot $\mathrm{N}$-content ranged from 0.96 to $2.12 \% \mathrm{~N}$, and was not related to compost $\mathrm{N}$ added or compost type. Carrot stems and leaves made up 53.8\% of the total harvested biomass of carrots. Total harvested plant biomass had an average $\mathrm{N}: \mathrm{P}$ ratio (by mass) of 8.63, compared to $\mathrm{N}: \mathrm{P}$ ratios of 6.88 and 2.83 for the municipal and manure compost.

The mass of $\mathrm{P}$ removed in the form of crop biomass ranged from 0.66 to $1.83 \mathrm{~g}$ P. Total $\mathrm{P}$ harvested was not related to compost $\mathrm{P}$ added $(P=0.85)$ but was higher for municipal compost $(P=0.0404)$ with a significant compost $\mathrm{P}$ added $\times$ compost type interaction term $(P=$ 0.0205) (Fig. 1A). The mass of $\mathrm{N}$ removed in the form of crop biomass ranged from 5.33 to $14.84 \mathrm{~g}$ N. Total $\mathrm{N}$ harvested increased with compost $\mathrm{N}$ added $(P=0.0044)$ and was higher for manure compost $(P=0.0002)$, with a significant compost $\mathrm{N}$ added $\times$ compost type interaction term $(P=0.0073)$ (Fig. 1B). Control plots (in which no compost was added) had a mean crop yield of $0.98 \mathrm{~g} \mathrm{P}$ and $8.27 \mathrm{~g} \mathrm{~N}$.

PUE ranged from 2 from $17 \%$ across plots. PUE was inversely related to compost $\mathrm{P}$ added $(P<0.0001)$. There was no effect of compost type $(P=0.1202)$, but there was a significant compost $\mathrm{P}$ added $\times$ compost type interaction term $(P=0.0499)$ (Fig. 2A). NUE ranged from 3 to $42 \%$ across plots. NUE was inversely related to compost $\mathrm{N}$ added $(P<0.0001)$, and was 
higher for municipal compost $(P=0.0031)$, with a significant compost $\mathrm{N}$ added $\times$ compost type interaction term $(P<0.0001)$ (Fig. 2B).

Cumulative $\mathrm{PO}_{4}{ }^{3}$ - leachate ranged from 0.00 to $0.95 \mathrm{~g} \mathrm{P}$ across plots. Cumulative $\mathrm{PO}_{4}^{3-}$ leachate increased with compost $\mathrm{P}$ added $(P<0.0001)$ and was higher for manure compost $(P<$ $0.0001)$, with a significant compost $\mathrm{P}$ added $\times$ compost type interaction term $(P=0.0002)$ (Fig. 3A). Cumulative inorganic $\mathrm{N}$ leachate ranged from 0.00 to $22.04 \mathrm{~g} \mathrm{~N}$ across plots.
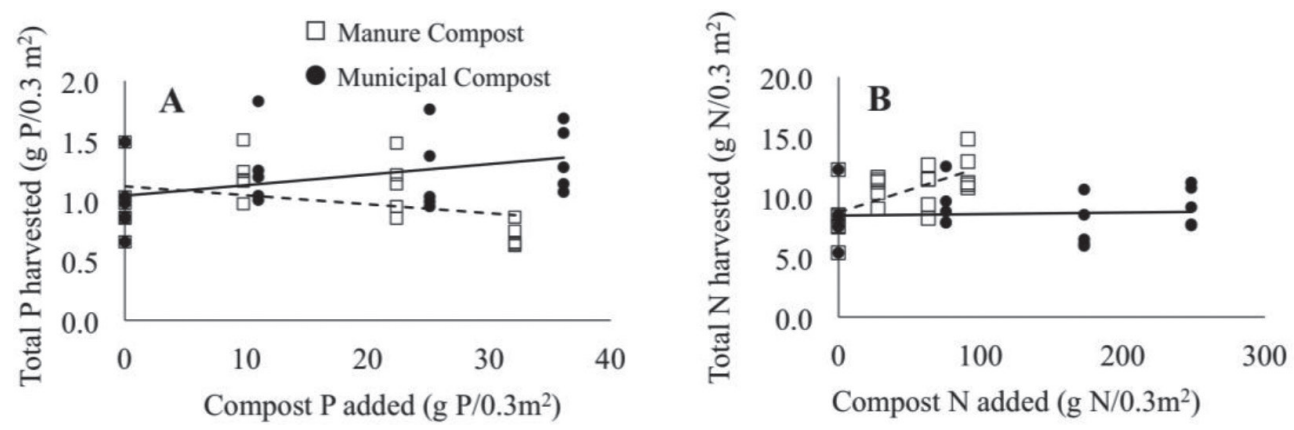

Figure 1: (A) Total $\mathrm{P}$ harvested versus compost $\mathrm{P}$ added for manure and municipal composts. (B) Total $\mathrm{N}$ harvested versus compost $\mathrm{N}$ added for manure and municipal composts.
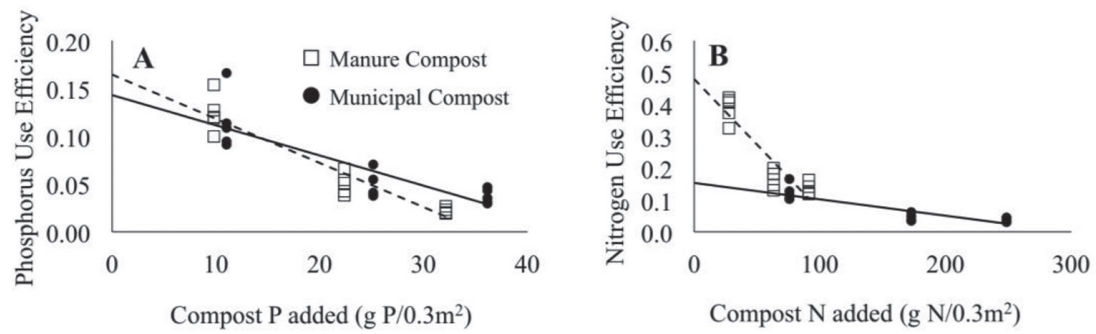

Figure 2: (A) Phosphorus use efficiency versus compost $\mathrm{P}$ added for manure and municipal composts. (B) Nitrogen use efficiency (defined as total $\mathrm{N}$ harvested relative to compost $\mathrm{N}$ added) versus compost $\mathrm{N}$ added for manure and municipal composts.
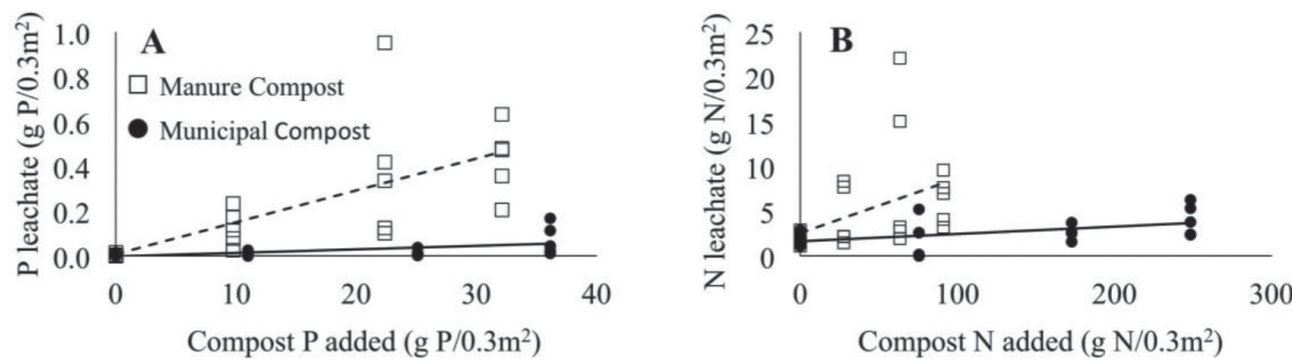

Figure 3: (A) $\mathrm{PO}_{4}{ }^{3}$ - leachate versus compost $\mathrm{P}$ added for manure and municipal composts. (B) Inorganic $\mathrm{N}\left(\mathrm{NO}_{3}-\& \mathrm{NH}_{4}^{+}\right)$leachate versus compost $\mathrm{N}$ added for manure and municipal composts. 
Cumulative inorganic $\mathrm{N}$ leachate increased with compost $\mathrm{N}$ added $(P=0.0060)$ and was higher for manure compost $(P=0.0008)$, with a significant compost $\mathrm{N}$ added $\times$ compost type interaction term $(P=0.0325)$ (Fig. 3B). Leachate had a mean volume-weighted $\mathrm{N}: \mathrm{P}$ mass ratio of 31 .

\section{DISCUSSION}

Our results support the hypotheses that PUE and NUE decreased, and that $\mathrm{P}$ and $\mathrm{N}$ leachate increased, with increasing compost $\mathrm{N}$ and $\mathrm{P}$ application. The low $\mathrm{N}: \mathrm{P}$ ratios of compost relative to crop biomass led to a greater application of $\mathrm{P}$ relative to $\mathrm{N}$, but this imbalance was partially offset by the high N:P ratio of leachate.

The positive relationship between crop yield and compost application is indicative of a tradeoff between production and nutrient use efficiency that has been documented in conventional agriculture [16]. The low nitrogen and phosphorus use efficiency values for the higher levels of compost application were consistent with results previously reported [17] for a 50:50 mixture (by volume) of different food-waste derived composts and soil, in which PUE ranged from 2 to $8 \%$ and NUE ranged from 3 to $17 \%$. These results suggest that efforts to recycle urban waste into urban food production may create additional negative externalities.

While compost treatments in this study applied nutrients at a level of up to 25 -fold greater than crop $\mathrm{N}$ demand and 36-fold greater than crop $\mathrm{P}$ demand, this rate of compost application is consistent with common practices in urban agriculture [13]. Because compost is a slowrelease fertilizer, with only a fraction of the total $\mathrm{N}$ and $\mathrm{P}$ becoming available to plants during the first year it is applied [18], [19], there may be a tendency among farmers and gardeners to over-apply compost if compost is applied annually based on anticipated crop $\mathrm{N}$ demand (i.e. without accounting for mineralization of older compost in the soil). Gardeners and urban farmers may apply large amounts of compost with goals of building soil organic matter and improving moisture retention. Our results show that low nutrient use efficiency and nutrient loss through leachate is a consequence of over-application of compost, not only for mobile nutrients such as $\mathrm{N}$ but also for $\mathrm{P}$. Manure compost is widely used in urban and peri-urban agriculture [20], but our results suggest that this soil amendment may be particularly prone to leaching $\mathrm{P}$ and $\mathrm{N}$, perhaps due to higher mineralization rates of labile organic matter, compounded by increased infiltration as a result of a very low bulk density (Table 1). The low N:P ratio of manure compost (ratio of 2.8; Table 1) also leads to a high rate of $\mathrm{P}$ build-up in the soil over time. One potential solutions may be to mix manure composts with feedstocks derived from woody wastes (i.e. woodchips, sawdust, woody mulch) that contain low P content and a higher $\mathrm{C}: \mathrm{N}$ ratio. Woody wastes contain recalcitrant forms of nutrients that break down slowly and limit the leaching of $\mathrm{P}$ and $\mathrm{N}$, and they can be added to a compost mix with a low $\mathrm{N}: \mathrm{P}$ ratio (i.e. manure compost) or low $\mathrm{C}: \mathrm{N}$ ratio (i.e. municipal compost in this case) to increase the overall $\mathrm{C}: \mathrm{N}$ ratio of the final product. Achieving greater $\mathrm{C}: \mathrm{N}$ ratio in the soil increases $\mathrm{C}$ availability, which promotes microbial immobilization of nutrients. $\mathrm{N}$ and $\mathrm{P}$ mineralization is subsequently reduced, and so is their availability for leaching or transformation to gaseous $\mathrm{N}_{2} \mathrm{O}$ [21]. Given the stoichiometry constraints of microbial nutrient use, a C:N ratio greater than 20 is recommended to promote immobilization of $\mathrm{N}$ as opposed to mineralization [22]. More research is needed in finding ways to make stoichiometric adjustments to compost blends used for urban agriculture to increase crop nutrient use efficiencies and decrease compost nutrient leaching while maintaining crop yields.

Our results showed lower $\mathrm{N}$ and $\mathrm{P}$ leachate fluxes for municipal compost (Fig. 3), but similar NUE and PUE for a given amount of compost $\mathrm{N}$ or $\mathrm{P}$ applied (Fig. 2), indicating that more of these nutrients were retained in the soil, presumably becoming available over 
subsequent years. With continued growth of urban agriculture in the United States [23] and worldwide [24] and increased efforts to divert organic wastes away from landfills as a climate change mitigation strategy and recycle within cities through composting, the application of composts on urban farms and gardens may be expected to increase. Our results indicate that, while this strategy recycles nutrients back into the human food system, it might also turn urban gardens into hotspots of pollution.

\section{ACKNOWLEDGEMENTS}

Zachary Beckman, Casey Clemenson, and Brandon Paulson contributed to field measurements and laboratory analyses. Catherine Grant provided support with plant propagation. This study was supported in part by a National Science Foundation CAREER award (award number 1651361) to G. E. Small.

\section{REFERENCES}

[1] Burger, J.R., Allen, C.D., Brown, J.H., Burnside, W.R., Davidson, A.D., Fristoe, T.S., Hamilton, M.J., Mercado-Silva, N., Nekola, J.C., Okie, J.G. \& Zuo, W., The Macroecology of Sustainablility. PLoS Biology 10, p. e1001345, 2012.

[2] Rees, W.E. \& Wackernagel, M., Appropriated carrying capacity: Measuring the natural capital requirements of the human economy. Investing in Natural Capital: Ecological Economics Approach to Sustainability, ed. A. Jansson, M. Hammer, C. Folke \& R. Costanza, Island Press: Washington, DC, pp. 362-390, 1994.

[3] Baker, L.A., Can urban $\mathrm{P}$ conservation help to prevent the brown devolution? Chemosphere, 84(6), pp. 779-784, 2011. https://doi.org/10.1016/j.chemosphere.2011. 03.026

[4] Grewal, S.S. \& Grewal, P.S., Can cities become self-reliant in food? Cities 29(1), pp. 1-11, 2012. https://doi.org/10.1016/j.cities.2011.06.003

[5] Brown, K. \& Jameton, A., Public health implications of urban agriculture. Journal of Public Health Policy, 21(1), pp. 20-39, 2000. https://doi.org/10.2307/3343472

[6] Smit, J. \& Nasr, J., Urban agriculture for sustainable cities: using wastes and idle land and water bodies as resources. Environment and Urbanization, 4(2), pp. 141-152, 1992. https://doi.org/10.1177/095624789200400214

[7] Kleinman, P.J.A., Allen, A.L., Needelman, B.A., Sharpley, A.N., Vadas, P.A., Saporito, L.S., Folmar, G.J. \& Bryant, R.B., Dynamics of phosphorus transfers from heavily manured coastal plain soils to drainage ditches. Journal of Soil and Water Conservation, 62, pp. 225-235, 2007.

[8] Heckrath, G., Brookes, P.C., Poulton, P.R. \& Goulding, K.W.T., Phosphorus leaching from soils containing different phosphorus concentrations in the Broadbalk experiment. Journal of Environmental Quality, 24(5), pp. 904-910, 1995. https://doi.org/10.2134/jeq1995.00472425002400050018x

[9] Sharpley, A., Jarvie, H.P., Buda A., May, L., Spears, B. \& Kleinman, P., Phosphorus legacy: Overcoming the effects of past management practices to mitigate future water quality impairment. Journal of Environmental Quality, 42(5), pp. 1308-1326, 2014. https://doi.org/10.2134/jeq2013.03.0098

[10] Taylor, J.R. \& Taylor Lovell, S., Urban home food gardens in the Global North: Research traditions and future directions. Agriculture and Human Values, 31(2), pp. 285-305, 2014. https://doi.org/10.1007/s10460-013-9475-1

[11] Rosen, C.J., Bierman, P.M. \& Eliason, R.D., Soil Test Interpretations and Fertilizer Management for Lawns, Turf, Gardens, and Landscape Plants. University of Minnesota Extension, St. Paul, MN, 2008. 
[12] Dewaelheyns, V., Elsen, A., Vandendriessche, H. \& Gulinck, H., Garden management and soil fertility in Flemish domestic gardens. Landscape and Urban Planning, 116, pp. 25-35, 2013. https://doi.org/10.1016/j.landurbplan.2013.03.010

[13] Metson, G.S. \& Bennett, E.M., Phosphorus cycling in Montreal's food and urban agriculture systems. PLOS ONE, 10(3), p. e0120726, 2015. https://doi.org/10.1371/ journal.pone.0120726

[14] Abdulkadir, A., Leffelaar, P.A., Agbenin, J.O. \& Giller K.E., Nutrient flows and balances in urban and peri-urban agroecosystems of Kano, Nigeria. Nutrient Cycling in Agroecosystems, 95(2), pp. 231-254, 2015. https://doi.org/10.1007/s10705-013-9560-2

[15] Murphy, J. \& Riley, J.P., A modified single solution method for the determination of phosphate in natural waters. Analytical Chimica Acta, 27, pp. 31-36, 1962. https://doi.org/10.1016/s0003-2670(00)88444-5

[16] Tilman, D., Global environmental impacts of agricultural expansion: The need for sustainable and efficient practices. Proceedings of the National Academy of Sciences of the United States of America, 96(11), pp. 5995-6000, 1999. https://doi.org/10.1073/pnas.96.11.5995

[17] Small, G.E., Sisombath, B., Reuss, L., Henry, R. \& Kay, A.D., Assessing how the ratio of barley mash to wood chips in compost affects rates of microbial processing and subsequent vegetable yield. Compost Science \& Utilization, 25(4), pp. 272-281, 2017. https://doi.org/10.1080/1065657x.2017.1329038

[18] Amlinger, F., Götz, B., Dreher, P., Geszti, J. \& Weissteiner, C., Nitrogen in biowaste and yard waste compost: Dynamics of mobilization and availability - A review. European Journal of Soil Biology, 39(3), pp. 107-116, 2003. https://doi.org/10.1016/s11645563(03)00026-8

[19] Gabrielle, B., Da-Silveira, J., Houot, S. \& Michelin, J., Field-scale modelling of carbon and nitrogen dynamics in soils amended with urban waste composts. Agriculture, Ecosystems \& Environment, 110(3-4), pp. 289-299, 2005. https://doi.org/10.1016/j. agee.2005.04.015

[20] Edmondson, J.L., Davies, Z.G., Gaston, K.J. \& Leake, J.R., Urban cultivation in allotments maintains soil qualities adversely affected by conventional agriculture. Journal of Applied Ecology, 51(4), pp. 880-889, 2014. https://doi.org/10.1111/1365-2664.12254

[21] Booth, M.S., Stark, J.M. \& Rastetter, E., Controls on nitrogen cycling in terrestrial ecosystems: a synthetic analysis of literature data. Ecological Monographs, 75(2), pp. 139-157, 2005. https://doi.org/10.1890/04-0988

[22] Chapin, F.S., Matson, P.A. \& Vitousek, P.M., Nutrient cycling. Principles of Terrestrial Ecosystem Ecology, pp. 259-296, Springer: New York, 2011.

[23] Palmer, L., Urban agriculture growth in US cities. Nature Sustainability, 1(1), pp. 5-7, 2018. https://doi.org/10.1038/s41893-017-0014-8

[24] Lee-Smith, D., Cities feeding people: An update on urban agriculture in equatorial Africa. Environment and Urbanization, 22(2), pp. 483-499, 2010. https://doi.org/10.1177/0956247810377383 